Шимко Я. Р.

\title{
ПІДХОДИ ДО НОРМАТИВНО-ПРАВОВОГО РЕГУЛЮВАННЯ ДІЯЛЬНОСТІ НЕДЕРЖАВНИХ ПЕНСІЙНИХ ФОНДІВ
}

\begin{abstract}
Розроблено схематичне уявлення про специфіку функціонування недержавних пенсійних фондів (НПФ). Визначено основні елементи нормативно-правового регулювання діяльності професійних адміністраторів та компаній з управління активами НПФ в Украӥні. Обтрунтовано ключовий стимул у розвитку НПФ - податкові пільги зі сплати податку на доходи фізичних осіб з обов 'язковим урахуванням виду пенсійної виплати. З'ясовано особливості формування структури інвестиційного портфеля НПФ 3 огляду на застосовувані обмеження. Доведено дочільність процесу саморегулювання через ідентифікацію основних переваг зазначеного процесу. Узагальнено комплекс заходів, спрямованих на досягнення гнучкості системи регулювання діяльності НПФ.
\end{abstract}

Ключові слова: недержавні пенсійні фонди,державне регулювання, нормативно-правове регулювання, професійні адміністратори, компанії з управління активами, пенсійні накопичення, індивідуальний пенсійний рахунок, інвестиційний портфель, саморегулювання.

\begin{abstract}
Постановка проблеми. Розвиток недержавних пенсійних фондів (НПФ) здійснюється в умовах змінюваного ринкового середовища, у зв’язку 3 чим фонди постійно адаптують свою діяльність, пристосовуючись до ринкових перетворень. Така ситуація зумовлює необхідність актуалізації підходів до формування законодавчого підгрунтя діяльності фондів. У свою чергу, систематичне відслідковування змін, що відбуваються у функціонуванні НПФ, сприяє своєчасному управлінню діяльністю фондів у векторі, який найповніше відповідає фінансовим інтересам їх учасників. Тому з'ясування специфіки нормативно-правового регулювання діяльності НПФ є актуальною сферою наукових досліджень.
\end{abstract}

Аналіз останніх досліджень і публікацій. Результати досліджень державного регулювання діяльності НПФ висвітлювали у своїх працях такі науковці, як: Н.I. Балдич, К.А. Грем'яцька, Н.О. Небаба, Г.В. Татаренко, Н.А. Цікановська [1-5] та ін. Однак, незважаючи на значний науковий доробок у цій сфері, питання нормативноправового регулювання діяльності НПФ потребують постійного моніторингу в контексті змін, які відбуваються в фінансовому законодавстві, та 3 метою пошуку шляхів підвищення ефективності функціонування досліджуваних фінансових установ.

Формулювання цілей статті. Метою статті $є$ моніторинг сучасного стану нормативноправового регулювання діяльності НПФ задля визначення найбільш значущих стимулів у їх

(с) Шимко Я.Р., асистент, Кафедра фінансів Івано-Франківського національного технічного університету нафти і газу розвитку в частині податкових пільг, обмежень у інвестиційному портфелі та доцільності функціонування саморегулівних організацій.

Опис основного матеріалу дослідження 3 повним обгрунтуванням отриманих наукових результатів. Функціонування НПФ передбачає взаємопов'язану діяльність окремих спільно структурованих структур. Насамперед, це Рада фонду, до функціональності якої входить контроль за поточною діяльністю НПФ. При цьому, Голова та члени Ради НПФ проходять обов'язкове спеціальне навчання та отримують сертифікати спеціалістів з питань недержавного пенсійного забезпечення та повинні періодично актуалізувати свою кваліфікацію. Окрім того, згідно 3 Законом [6] до діяльності НПФ обов'язково залучаються:

- адміністратор фонду, на якого покладається відповідальність за пенсійні контракти, пенсійні рахунки та внески, пенсійні доходи та пенсійні виплати учасникам, складання та оприлюднення звітності;

- компанія 3 управління активами, котра організовує розміщення тимчасово вільних активів фонду відповідно до законодавчо встановлених вимог та формує профіль дохідності активів;

- банк-зберігач, до функцій якого входить здійснення розрахунково-касового, депозитарного обслуговування, обслуговування операцій з цінними паперами).

Відповідна схема функціонування НПФ представлена на рисунку 1 .

Адміністратор, компанія 3 управління активами та банк-зберігач можуть надавати послуги НПФ лише у випадку дотримання 


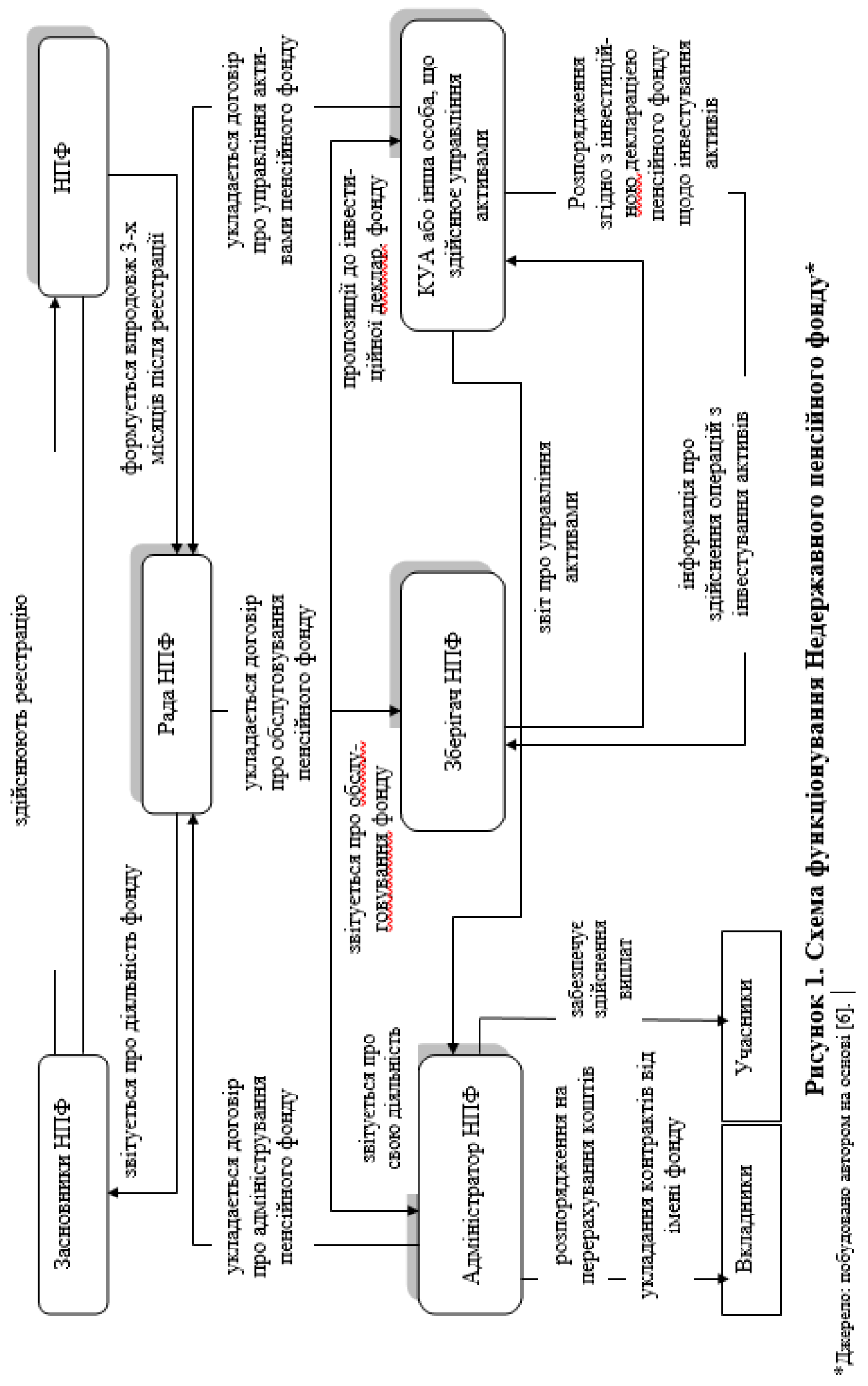


відповідних вимог, до яких слід віднести: ліцензійні вимоги до діяльності суб'єктів управління НПФ, вимоги до розмірів статутного капіталу компанії з управління активами та адміністратора НПФ, кваліфікаційні вимоги до працівників суб'єктів управління НПФ, вимоги до програмно-технічного забезпечення персоніфікованого обліку пенсійних накопичень учасників НПФ, граничні розміри оплати послуг установ, які обслуговують діяльність НПФ, тощо (табл.1).

Таблиця 1

Елементи нормативно-правового регулювання діяльності професійних адміністраторів та компаній з управління активами НПФ в Україні*

\begin{tabular}{|c|c|}
\hline Елементи регулювання & Нормативно-правові вимоги \\
\hline Статутний капітал професійного адміністратора & $\begin{array}{c}\text { Розмір статутного капіталу - не менше, ніж 2,5 } \\
\text { млн. грн. }\end{array}$ \\
\hline Власний капітал професійного адміністратора & $\begin{array}{c}\text { Розмір власного капіталу - не менше, ніж 2,5 млн. } \\
\text { грн. }\end{array}$ \\
\hline $\begin{array}{c}\text { Статутний капітал компанії з управління активами } \\
\text { НПФ }\end{array}$ & $\begin{array}{c}\text { Розмір статутного капіталу - не менше, ніж 7,0 } \\
\text { млн. грн. }\end{array}$ \\
\hline $\begin{array}{c}\text { Власний капітал компанії з управління активами } \\
\text { НПФ }\end{array}$ & $\begin{array}{c}\text { Розмір власного капіталу - не менше, ніж розмір } \\
\text { зареєстрованого статутного капіталу }\end{array}$ \\
\hline $\begin{array}{c}\text { Резервний фонд професійного адміністратора, } \\
\text { компанії з управління активами НПФ }\end{array}$ & $\begin{array}{c}\text { Підтримується у розмірі, не меншому, ніж } 25 \% \\
\text { від розміру статутного фонду. Розмір щорічних } \\
\text { відрахувань до резервного фонду не може бути } \\
\text { менше 5\% від суми чистого прибутку }\end{array}$ \\
\hline $\begin{array}{c}\text { Граничний розмір витрат, пов’язаних із } \\
\text { здійсненням недержавного пенсійного } \\
\text { забезпечення }\end{array}$ & $\begin{array}{c}\text { Річний граничний розмір витрат, що } \\
\text { відшкодовуються за рахунок пенсійних активів, } \\
\text { встановлюється у відсотках від чистої вартості } \\
\text { активів пенсійного фонду і становить 7\% }\end{array}$ \\
\hline
\end{tabular}

*Джерело: складено автором за даними [6-9].

Встановлені вимоги свідчать про те, що державна політика, проваджувана в сфері недержавного пенсійного забезпечення, зорієнтована не лише на зміцнення фондів, але i на перехід від кількісних характеристик їхньої діяльності до якісних. Так, кожний учасник НПФ має можливість один раз на рік перевести власні пенсійні активи до іншого фонду. Таке право введено як захисний захід від несумлінних фондів та управляючої компанії, однак це суттєво ускладнює процес інвестування фондів пенсійних накопичень. Така ситуація пояснюється наявністю короткострокового горизонту планування, що не дозволяє розміщувати кошти у високодохідні довгострокові проекти. У свою чергу, подовження терміну переведення пенсійних накопичень між фондами дозволить збільшити горизонт планування та, як наслідок, сприятиме зростанню дохідності фондів.

Одним зі стимулів розвитку НПФ є податкові пільги зі сплати податку на доходи фізичних осіб (рис.2). При цьому схема оподаткування залежить від виду пенсійної виплати.

Зокрема, за рахунок пенсійних накопичень на індивідуальному пенсійному рахунку учасники фонду можуть отримати наступні види виплат:

- по-перше, пенсія на визначений строк, що передбачає виплату пенсійних накопичень частинами впродовж 10 і більше років при настанні для учасника пенсійного віку, визначеного пенсійним контрактом;

- по-друге, виплата всієї суми пенсійних накопичень за один раз (т.зв. «одноразова пенсійна виплата»), що здійснюється у виняткових випадках, при настанні визначених законом підстав;

- по-третє, довічна пенсія, що виплачується страховою організацією, обраною учасником НПФ.

Пенсійна виплата на визначений строк або одноразова виплата всієї суми накопичень здійснюється адміністратором НПФ, до якого сплачувались внески вкладником, а довічна виплата - страховою організацією, обраною учасником. Дострокове отримання пенсійних виплат, забороняється. Така вимога встановлена для того, щоб учасник мав можливості використати накопичені кошти виключно для задоволення потреб, які виникнуть після виходу на пенсію. В умовах сьогодення роботодавці мають певну зацікавленість до участі в подібних програмах недержавного пенсійного забезпечення, що зумовлюється можливістю віднесення суми страхових внесків на собівартість у розмірі до $15 \%$ нарахованої працівникам заробітної плати, але не більш як 2,5 
розміру мінімальної заробітної плати, встановленої законом про Державний бюджет

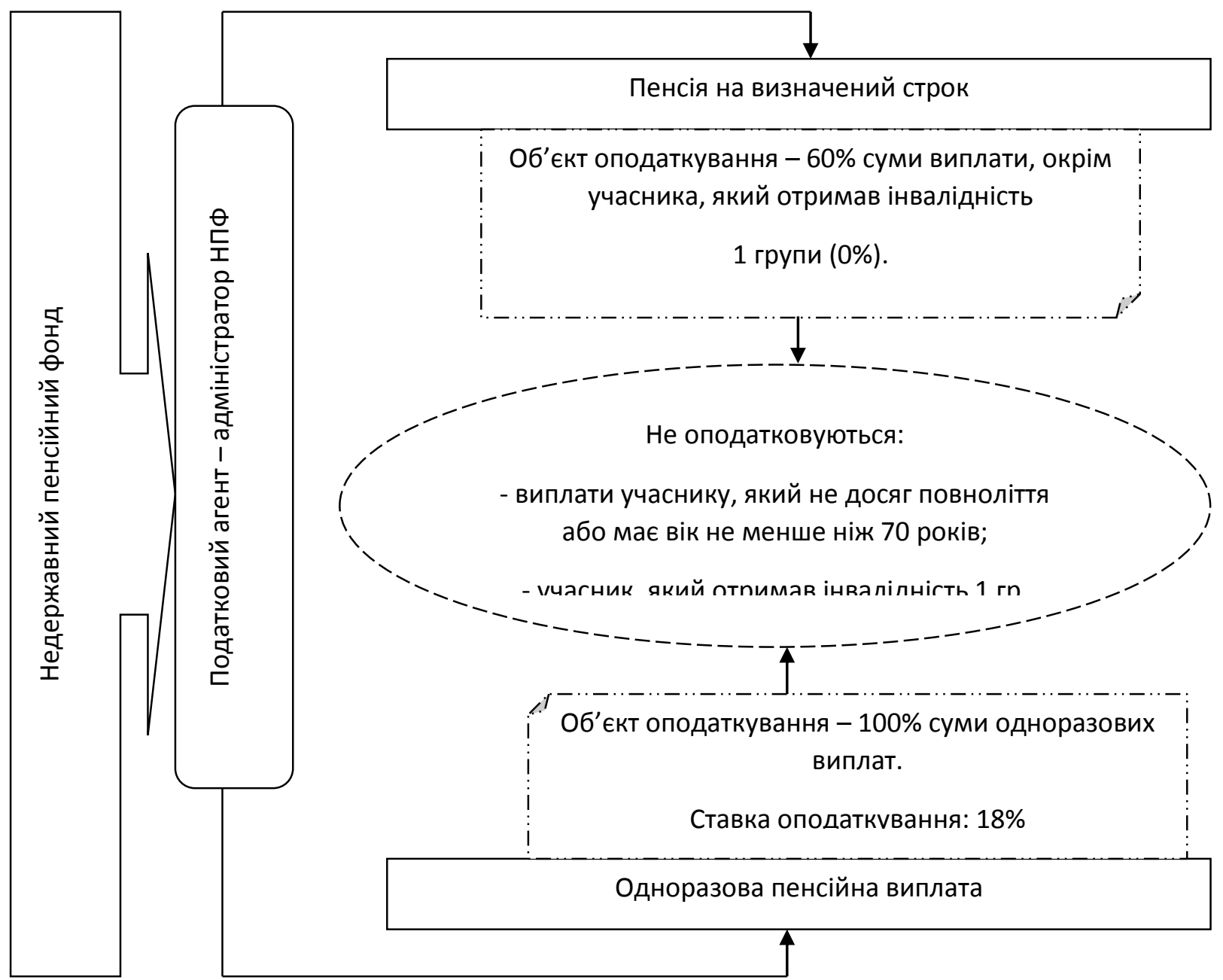

Рисунок 2. Особливості оподаткування виплат учасників НПФ*

*Джерело: побудовано автором на основі [10].

України на відповідний рік [10].

Розгляд проблематики державного неповним, якщо оминути увагою особливості формування структури інвестиційного портфеля НПФ. Варто зазначити, що до такого портфеля застосовуються такі обмеження:

- на концентрацію власності, тобто максимальна частка в процентах в акціонерному капіталі емітента;

- частка одного фінансового інструменту в інвестиційному портфелі фонду;

- $\quad$ частка цінних паперів одного емітента в інвестиційному портфелі фонду;

- рівень ризику, пов'язаного 3 певним активом, що характеризується рейтингом емітента;

- перелік емітентів, яким присвоєний регулювання діяльності та розвитку НПФ буде

рейтинг не нижче встановленого;

- перелік цінних паперів 3 наявними котирувальними паперами торгових площадок [11].

Якщо згрупувати основні категорії цінних паперів, в які можуть інвестувати кошти НПФ, за ступенем ризику, то можна виділити такі три групи:

- умовно-безризикові активи, до них відносяться банківські депозити, державні облігації та боргові зобов'язання державних компаній, за якими уряд виступає гарантом;

- ризикові активи - ліквідні корпоративні, місцеві облігації 3 високим інвестиційним рейтингом; 
- високо-ризикові активи - акції та корпоративні боргові зобов'язання, в том числі не включені до біржового лістингу, похідні інструменти та ін.

Часто регулюючий орган визначає максимальне процентне співвідношення вартості високо ризикових активів у загальній вартості активів, а також мінімальну частку умовнобезризикових інструментів. А інша частина коштів може бути інвестована у ринкові інструменти з низьким ризиком.

Загальні обмеження інвестиційної діяльності 3 пенсійними активами НПФ, встановлені Законом України [6], представлені на рис.3.

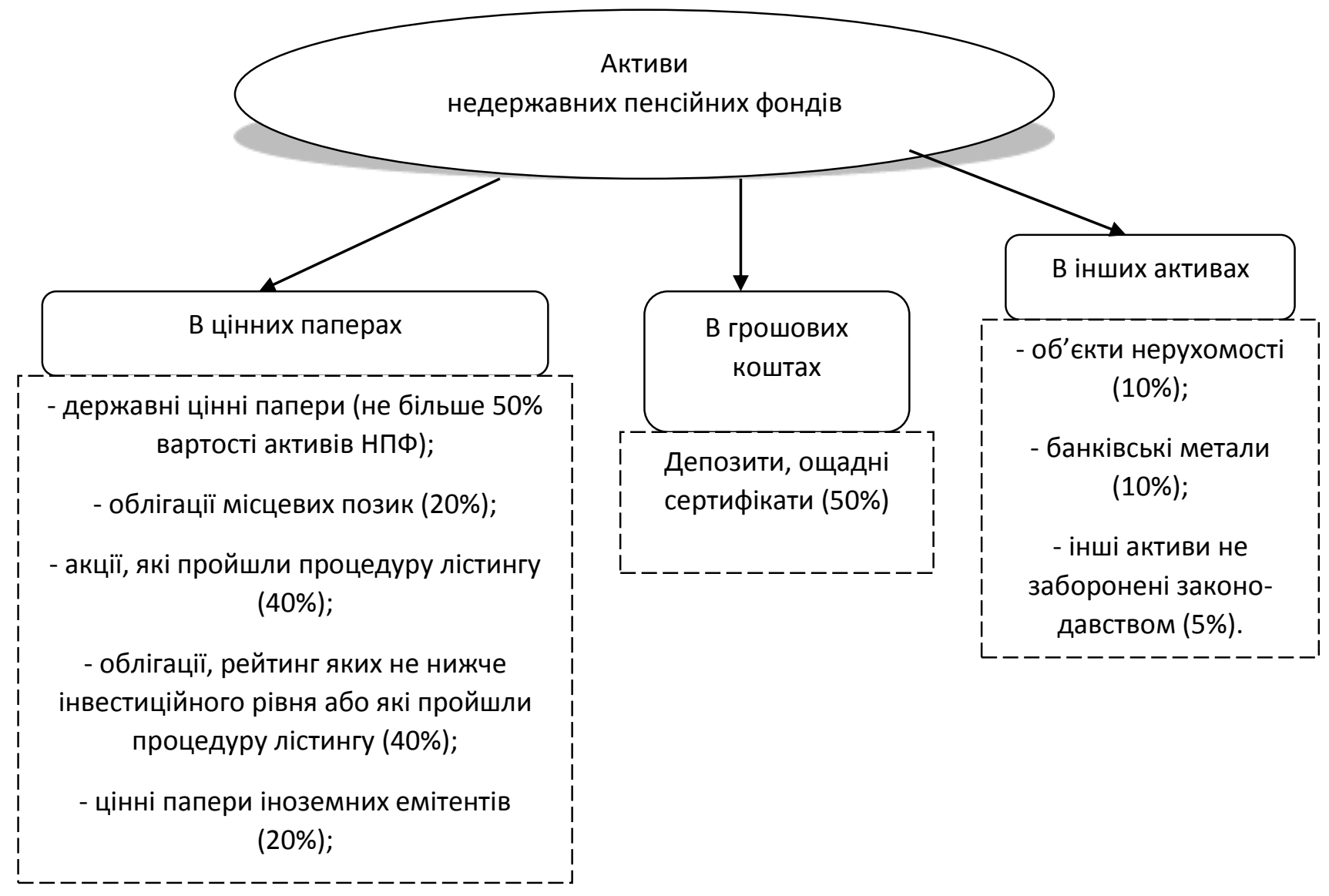

Рисунок 3. Загальні обмеження інвестиційної діяльності з пенсійними активами НПФ*

*Джерело: складено автором за [6].

Важливим дискусійним питанням $\epsilon$ доцільність встановлення лімітів інвестування в іноземні активи. Варто зазначити, що іноземні інвестиції сприяють диверсифікації країнового ризику, який виникає в разі домінування активів і пасивів фонду в однаковій валюті. Розмежування активів фонду серед сукупності інструментів різних країн зумовлює зменшення мінливості дохідності сукупного інвестиційного портфеля. Обгрунтованість інвестування в іноземні активи виникає також у випадку відсутності можливості ефективного розміщення фінансових ресурсів усередині країни, коли внутрішній ринок капіталу $\epsilon$ недостатньо розвиненим. Разом із тим, встановлення обмежень на інвестування в іноземні активи на тлі сприятливих прогнозів економічного розвитку може сприяти розвитку внутрішнього ринку капіталу. При цьому, слід зважати на те, що інвестування коштів за кордон призводить до активізації валютного ризику, отже фіксування таких обмежень спрямовується, насамперед, на уникнення зазначеного ризику.

Окрім регулювання структури інвестиційного портфеля держава може встановлювати реальну або номінальну, абсолютну або відносну мінімальну цільову дохідність портфеля. В якості еталонного рівня правомірним $є$ використання дохідності ринкового портфеля або середньої дохідності портфелів усіх пенсійних фондів.

Так, Законом України [6] передбачене зобов'язання компанії 3 управління активами забезпечувати мінімальну дохідність пенсійних активів на рівні офіційного індексу інфляції у разі встановлення такої вимоги Радою НПФ. Також законом передбачене право змінити компанію 3 
управління активами у разі зменшення чистої вартості одиниці пенсійних активів НПФ впродовж року більш, ніж на $20 \%$.

Для компенсації збитків, завданих учасникам НПФ при реалізації операційних та кредитних ризиків, Законом України [6] передбачена майнова відповідальність адміністраторів та компаній з управління активами, а саме, виплата відшкодування за рахунок резервного фонду, а у разі його недостатності - за рахунок іншого майна. Зберігач також несе майнову відповідальність за збитки, завдані ним учасникам НПФ внаслідок невиконання або неналежного виконання умов договору про обслуговування фонду зберігачем, та відшкодовує їх відповідно до умов договору та у порядку, встановленому законодавством. Законом передбачена майнова відповідальність членів ради, однак підстави i механізм притягнення до такої відповідальності не врегульовані.

Законом України [6] обмежено види пенсійних схем, які дозволено використовувати НПФ, зокрема, не передбачено схем із визначеними виплатами. Це дозволяе запобігти невиконанню зобов'язань НПФ у разі недостатнього обсягу пенсійних накопичень для виплати таких пенсій учасникам фонду. Звідси зрозуміло, що інвестиційні ризики перекладені безпосередньо на учасників фонду.

Зазвичай, законодавчі обмеження структури інвестиційного портфеля НПФ дещо послаблюються в процесі розвитку пенсійної системи та підвищення ефективності функціонування фінансового ринку, оскільки такі обмеження обумовлюють недоотримання інвестиційного прибутку внаслідок втраченої вигоди, що, відповідно, зменшує майбутні пенсійні накопичення, забезпечувані фондам.

У країнах із розвиненими ринками капіталів та культурою прийняття інвестиційних рішень держава підтримує лише основоположні пруденційні обмеження та застосовує «правило розумного інвестора», відповідно до якого управлінець повинен діяти як «розумний та обачливий професіонал, який чітко розуміється на фінансових питаннях, володіє достатнім досвідом та має відповідний рівень освіти» [12]. За нашими міркуваннями, поведінка економічних агентів у таких випадках має контролюватися саморегулівними асоціаціями.

В Україні функціонують такі саморегулівні організації, які контролюють діяльність НПФ та установ, що управляють фондами: Національна асоціація недержавних пенсійних фондів України та Адміністраторів недержавних пенсійних фондів, Українська асоціація адміністраторів пенсійних фондів, Українська Асоціація інвестиційного бізнесу, Професійна асоціація учасників ринків капіталу та деривативів, тощо.

Сутнісне наповнення саморегулювання характеризується розробкою та визначенням стандартів і правил щодо пропонованих послуг, а також контролем за їх дотриманням, який проваджується 3 метою захисту інтересів як учасників саморегулівних організацій (СРО), так і споживачів послуг.

Чим же викликана потреба в саморегулюванні? Відповідь на це запитання, на нашу думку, розкривається через ідентифікацію основних переваг зазначеного процесу. До них можна віднести:

- еластичність норм СРО на відміну від державних, та швидка адаптованість до змін геополітичної, соціально-економічної та політичної ситуацій на ринку;

- можливість впливу на органи державної влади задля позиціонування професійних інтересів суспільства за допомогою встановлення діалогу між владою та бізнесом. Такий вплив зумовлюється участю в розробці законопроектів, просування своїх представників до складу виборних органів державної влади та ін.;

- формування механізму досудового розгляду тих чи інших ситуацій, що виникають між споживачами різноманітних фінансових послуг та фінансовими установами. За результатами дослідження зарубіжного досвіду провадження таких заходів є більш економічним та оперативним, аніж процедура судового розгляду;

- впровадження кращих практик професійного регулювання сфери пенсійного забезпечення.

Отже, можна зробити висновок, що функціонування саморегулівних організацій зумовлює, в тому числі відкритість та соціальну відповідальність НПФ.

Немаловажним завданням є також введення інституту пруденційного регулювання та пруденційного нагляду за діяльністю НПФ, що передбачено Концепцією запровадження пруденційного нагляду за небанківськими фінансовими установами [13] та Концепцією запровадження пруденційного нагляду за діяльністю професійних учасників фондового ринку [14]. При цьому, ключовою метою пруденційного нагляду, в першу чергу, $\epsilon$ запобігання порушенням, а не застосування адміністративних заходів у вигляді штрафів, призупинення або взагалі анулювання ліцензій, та iн. 3 огляду на таке, система регулювання 
повинна бути більш гнучкою за рахунок регулятора до СРО; підвищення довіри проведення комплексу заходів, таких як: споживачів фінансових послуг, які представлені підвищення вимог до крупних НПФ; зміна нижче (табл.2).

ліцензійних умов; передача частини функцій від

Таблиця 2

Узагальнення заходів, спрямованих на досягнення гнучкості системи регулювання діяльності НПФ*

\begin{tabular}{|c|c|c|}
\hline № 3/п & Назва заходу & Коротка характеристика \\
\hline 1. & $\begin{array}{c}\text { Підвищені вимоги до } \\
\text { крупних НПФ }\end{array}$ & $\begin{array}{l}\text { Формування підгрунтя фінансової безпеки для крупних гравців, яким } \\
\text { більшою мірою властиві системні ризики, порівняно } 3 \text { діяльність } \\
\text { невеликих компаній, для яких має дотримуватися відповідність } \\
\text { мінімально-визначеним вимогам. Завдяки цьому, вимоги до величини } \\
\text { власних коштів учасників фінансового ринку диференціюватимуться } \\
\text { залежно до обраного критерію. }\end{array}$ \\
\hline 2. & Зміна ліцензійних умов & $\begin{array}{l}\text { Наявність у регулятора можливості через послаблення або посилення } \\
\text { ліцензійних вимог контролювати кількісний та якісний склад учасників, } \\
\text { рівень конкурентної боротьби на ринку, а також встановлювати критерії } \\
\text { входу на ринок нових гравців. Відмітимо, що з огляду на існуючу } \\
\text { динаміку укрупнення гравців фінансового ринку, можна спрогнозувати } \\
\text { подальшу тенденцію посилення ліцензійних вимог та, як наслідок, } \\
\text { скорочення учасників за рахунок об'єднання існуючих або припинення } \\
\text { діяльності окремих економічних агентів. }\end{array}$ \\
\hline 3. & $\begin{array}{c}\text { Передача частини } \\
\text { функцій від регулятора } \\
\text { до СРО }\end{array}$ & $\begin{array}{l}\text { Відповідно аналізу зарубіжного досвіду, позитивним є виконання певних } \\
\text { функцій регулятора саме СРО (наприклад, супровід процедур } \\
\text { ліцензування, атестація спеціалістів, проведення перевірок членів таких } \\
\text { саморегулівних організацій, тощо). }\end{array}$ \\
\hline 4. & $\begin{array}{c}\text { Підвищення довіри } \\
\text { споживачів фінансових } \\
\text { послуг }\end{array}$ & $\begin{array}{l}\text { Активізація провадження заходів із підвищення фінансової грамотності } \\
\text { населення, зміна системи оподаткування } 3 \text { огляду на зростання } \\
\text { привабливості інвестицій } \text { в інструменти фінансового ринку, } \\
\text { ідентифікація та перешкоджання діяльності фінансових пірамід, тощо. А } \\
\text { також, розгляд можливостей створення інституту фінансових } \\
\text { омбудсменів, формування компенсаційних фондів при СРО. }\end{array}$ \\
\hline
\end{tabular}

*Джерело: складено автором.

Висновки i перспективи подальших досліджень у даному напрямку. Підводячи підсумок вищезазначеному, слід відмітити, що в Україні одночасно з розвитком НПФ поступово вдосконалювалась і система державного регулювання діяльності в галузі недержавного пенсійного забезпечення, нагляду та контролю за діяльністю фондів. За результатами наукового аналізу доведено, що система регулювання повинна бути більш гнучкою за рахунок проведення комплексу заходів, таких як: підвищення вимог до крупних НПФ; зміна ліцензійних умов; передача частини функцій від регулятора до СРО; підвищення довіри споживачів фінансових послуг.

Напрямками подальшого наукового дослідження є ідентифікація переваг та ризиків функціонування недержавних пенсійних фондів 3 огляду на тенденції глобалізації фінансового середовища.

\section{СПИСОК ВИКОРИСТАНИХ ДЖЕРЕЛ}

1. Балдич Н. Регулювання інвестиційних ризиків у системі недержавного пенсійного забезпечення / Н. Балдич // Вісник Національної академії державного управління при Президентові України. - 2011. - Вип. 1. - С. $217-225$. 2. Грем'яцька К.А. Регулювання та контроль у системі недержавного пенсійного забезпечення [Електронний pecypc] / К.А. Грем’яцька // Державне будівництво. - 2007. - № 1. - Режим доступу: http://www.nbuv.gov.ua/ejournals/Debu/2007-1/doc/2/12.pdf.

3. Небаба Н.О. Державне регулювання системи недержавного пенсійного забезпечення: сучасний стан та напрями розвитку / Н.О. Небаба // Проблеми і перспективи розвитку банківської системи України: збірник наукових праць. - Суми: ДВНЗ «УАБС НБУ», 2013. - Вип. 37. - С. 326-334.

4. Татаренко Г.В. Державне регулювання недержавного пенсійного забезпечення / Г.В. Татаренко // Юридична наука, практика і освіта. - 2010. - Вип. 1. - С. 132-141.

5. Цікановська Н.А. Концептуальні основи державної політики у сфері недержавного пенсійного забезпечення / Н.А. Цікановська // Вісник Університету банківської справи Національного банку України. - 2014. - № 2(20). C. 28-32. 
6. Про недержавне пенсійне забезпечення: Закон України від 09.07.2003 № 1057-IV [Електронний ресурс]. Режим доступу: https://zakon.rada.gov.ua/laws/show/1057-15.

7. Про затвердження Ліцензійних умов провадження професійної діяльності на фондовому ринку (ринку цінних паперів) - діяльності з управління активами інституційних інвесторів (діяльності з управління активами): Рішення НКЦПФР від 23.07.2013 № 1281 [Електронний ресурс]. - Режим доступу: https://zakon.rada.gov.ua/laws/show/z1576-13.

8. Про затвердження Положення про особливості здійснення діяльності з управління активами інституційних інвесторів: Рішення НКЦПФР від 06.08.2013 № 1414 [Електронний ресурс]. - Режим доступу: https://zakon.rada.gov.ua/laws/show/z1486-13.

9. Про затвердження Положення про граничний розмір витрат, пов'язаних із здійсненням недержавного пенсійного забезпечення: Розпорядження Нацкомфінпослуг України від 04.12.2012 № 2541 [Електронний pecypc]. - Режим доступу: https://zakon.rada.gov.ua/laws/show/ z0226-13.

10.Податковий кодекс України від 2 грудня 2010 року № 2755-VI [Електронний ресурс]. - Режим доступу: https://zakon.rada.gov.ua/laws/show/ 2755-17\#n3850.

11. Reisen H. Liberalizing Foreign Investments by Pension Funds: Positive and Normative Aspects / H. Reisen // World Development. - 1997. - Volume 25, Issue 7. - P. 1173-1182.

12. Verbruggen P. Does Co-Regulation Strengthen EU Legitimacy? / P. Verbruggen // European Law Journal. - 2009. Vol. 15, n. 4. - P. 425-441.

13.Про затвердження Концепції запровадження пруденційного нагляду за небанківськими фінансовими установами та Програми розвитку системи пруденційного нагляду за небанківськими фінансовими установами: Розпорядження Держкомфінпослуг 15.07.2010 № 585 [Електронний ресурс]. - Режим доступу: https://zakon.rada.gov.ua/rada/show/vr585486-10.

14.Про схвалення Концепції запровадження пруденційного нагляду за діяльністю професійних учасників фондового ринку: Рішення НКЦПФР від12.04.2012 № 553 [Електронний ресурс]. - Режим доступу: https://zakon.rada.gov.ua/rada/show/vr553863-12.

\section{REFERENCES}

1. Baldych, N. (2011). Rehuliuvannia investytsiinykh ryzykiv u systemi nederzhavnoho pensiinoho zabezpechennia [Regulation of investment risks in the system of non-state pension provision]. Visnyk Natsionalnoi akademii derzhavnoho upravlinnia pry Prezydentovi Ukrainy - Bulletin of the National Academy of Public Administration under the President of Ukraine, 1, 217-225 [in Ukrainian].

2. Hremiatska, K.A. (2007). Rehuliuvannia ta kontrol u systemi nederzhavnoho pensiinoho zabezpechennia [Regulation and control in the system of non-state pension provision]. Derzhavne budivnytstvo - State construction, 1 . Retrieved from: http://www.nbuv.gov.ua/e-journals/Debu/2007-1/doc/2/12.pdf [in Ukrainian].

3. Nebaba, N.O. (2013). Derzhavne rehuliuvannia systemy nederzhavnoho pensiinoho zabezpechennia: suchasnyi stan ta napriamy rozvytku [State regulation of the system of non-state pension provision: the current state and directions of development]. Problemy i perspektyvy rozvytku bankivskoi systemy Ukrainy - Problems and prospects of development of the banking system of Ukraine, 37, 326-334 [in Ukrainian].

4. Tatarenko H.V. (2010). Derzhavne rehuliuvannia nederzhavnoho pensiinoho zabezpechennia [State regulation of nonstate pension provision]. Yurydychna nauka, praktyka i osvita - Law science, practice and education, 1, 132-141 [in Ukrainian].

5. Tsikanovska, N.A. (2014). Kontseptualni osnovy derzhavnoi polityky u sferi nederzhavnoho pensiinoho zabezpechennia [Conceptual bases of state policy in the field of non-state pension provision]. Visnyk Universytetu bankivskoi spravy Natsionalnoho banku Ukrainy - Bulletin of the University of Banking of the National Bank of Ukraine, 2(20), 28-32 [in Ukrainian].

6. Pro nederzhavne pensiine zabezpechennia: Zakon Ukrainy vid 09.07.2003 № 1057-IV [About non-state pension provision: Law of Ukraine dated 09.07.2003 No. 1057-IV]. Retrieved from: https://zakon.rada.gov.ua/laws/show/105715 [in Ukrainian].

7. Pro zatverdzhennia Litsenziinykh umov provadzhennia profesiinoi diialnosti na fondovomu rynku (rynku tsinnykh paperiv) - diialnosti z upravlinnia aktyvamy instytutsiinykh investoriv (diialnosti z upravlinnia aktyvamy): Rishennia NKTsPFR vid 23.07.2013 № 1281 [On Approval of Licensing Conditions for the Performance of Professional Activities in the Stock Market (Securities Market) - Asset Management Activities of Institutional Investors (Asset Management Activities): Decision of the Securities and Stock Market Commission dated July 23, 2013, No. 1281]. Retrieved from: https://zakon.rada.gov.ua/laws/show/z1576-13 [in Ukrainian].

8. Pro zatverdzhennia Polozhennia pro osoblyvosti zdiisnennia diialnosti z upravlinnia aktyvamy instytutsiinykh investoriv: Rishennia NKTsPFR vid 06.08.2013 № 1414 [On Approval of the Regulation on the Peculiarities of the Activity of Asset Management of Institutional Investors: Decision of the Securities and Stock Market Commission dated June 8, 2013, No. 1414]. Retrieved from: https://zakon.rada.gov.ua/laws/show/z1486-13 [in Ukrainian].

9. Pro zatverdzhennia Polozhennia pro hranychnyi rozmir vytrat, poviazanykh iz zdiisnenniam nederzhavnoho pensiinoho zabezpechennia: Rozporiadzhennia Natskomfinposluh Ukrainy vid 04.12.2012 № 2541 [On approval of the Regulations on the maximum amount of expenses related to the implementation of non-state pension provision: Order of 
the National Commission for State Regulation of Financial Services Markets of Ukraine dated December 4, 2012, № 2541]. Retrieved from: https://zakon.rada.gov.ua/laws/show/z0226-13 [in Ukrainian].

10. Podatkovyi kodeks Ukrainy vid 2 hrudnia 2010 roku № 2755-VI [The Tax Code of Ukraine dated December 2, 2010 No. 2755-VI]. Retrieved from: https://zakon.rada.gov.ua/laws/show/2755-17\#n3850 [in Ukrainian].

11. Reisen, H. (1997). Liberalizing Foreign Investments by Pension Funds: Positive and Normative Aspects. World Development, 25, 1173-1182 [in English].

12. Verbruggen, P. (2009). Does Co-Regulation Strengthen EU Legitimacy? European Law Journal, 15, $425-441$ [in English].

13. Pro zatverdzhennia Kontseptsii zaprovadzhennia prudentsiinoho nahliadu za nebankivskymy finansovymy ustanovamy ta Prohramy rozvytku systemy prudentsiinoho nahliadu za nebankivskymy finansovymy ustanovamy: Rozporiadzhennia Derzhkomfinposluh 15.07.2010 № 585 [On Approval of the Concept for the Implementation of Prudential Supervision for Non-Bank Financial Institutions and the Program for the Development of the Prudential Supervision System for Non-Bank Financial Institutions: Order of the State Committee for Financial Services of Ukraine dated July 15, 2010 No. 585]. Retrieved from: https://zakon.rada.gov.ua/rada/show/vr585486-10 [in Ukrainian].

14. Pro skhvalennia Kontseptsii zaprovadzhennia prudentsiinoho nahliadu za diialnistiu profesiinykh uchasnykiv fondovoho rynku: Rishennia NKTsPFR vid12.04.2012 № 553[On Approval of the Concept for the Implementation of Prudential Supervision over the Professional Stock Market Participants: Decision of the Securities and Stock Market Commission dated April 12, 2012 No. 553]. Retrieved from: https://zakon.rada.gov.ua/rada/show/vr553863-12 [in Ukrainian].

Одержано 14.03.2019 